\title{
Analysis of Retailer and Corporate Payment Habits in Hungary*
}

\author{
Vivien Deák - László Kajdi-István Nemecskó
}

The study looks at the payment habits of retailers and companies in Hungary, especially the acceptance and share of electronic payments in 2019. In doing so, data from two questionnaire-based surveys and the online cash register database are analysed using statistical methods, decision trees and regressions. The results show that retailer payments are typically cash intensive, while credit transfer transactions dominate at companies. The factors with the largest impact on card acquiring and the share of cash at points of sale is sales revenue and the value of the purchase in the case of retailers, and the proportion of cash wage payments in the case of companies. Costs also play an important role in card acquiring, therefore instant payment, which provides cheaper electronic payment solutions, could be crucial when it comes to smaller retailers and companies offering electronic payments. Public policy measures could mainly target retailers and the micro and small enterprise segment.

Journal of Economic Literature (JEL) codes: G20, D12, R11

Keywords: payments, card acquiring, SME, retailers

\section{Introduction}

The Magyar Nemzeti Bank (MNB, the Central Bank of Hungary) continuously examines the payment habits of various economic actors, in particular monitoring the possibility and extent of electronic payments. This is important for broadening knowledge on payments in general, but also because, as Bartha et al. (2017, p. 310) showed by summarising different analyses and results, the widespread use of electronic payments has a positive impact on the economy, a more efficient payments system is beneficial for economic competitiveness and growth, and when payments are cheaper for society as a whole, that also boosts the economy by releasing resources, improving the efficiency of companies and reducing the shadow economy. The MNB regularly conducts surveys on payment habits in the

\footnotetext{
* The papers in this issue contain the views of the authors which are not necessarily the same as the official views of the Magyar Nemzeti Bank.

Vivien Deák is an Analyst at the Magyar Nemzeti Bank. Email: deakv@mnb.hu

László Kajdi is a Senior Economic Analyst at the Magyar Nemzeti Bank.Email: kajdil@mnb.hu

István Nemecskó is an Analyst at the Magyar Nemzeti Bank. Email: nemecskoi@mnb.hu
}

The Hungarian manuscript was received on 11 March 2021.

DOI: http://doi.org/10.33893/FER.20.2.3359 
Hungarian household and corporate sectors. The advantage of these surveys is that while in many cases the comprehensive administrative and bank reporting allows major payment trends to be tracked with great accuracy, the information gained from more detailed databases (such as the online cash register database) and the surveys providing even more additional information enable the identification of underlying correlations. This is especially important from the perspective of the state and the central bank because it may strongly facilitate efficient public policy measures fostering the widespread use of electronic payments.

Recent public policy measures have also significantly influenced the Hungarian payment market, particularly the corporate and retailer segment. One only needs to think of the public POS terminal deployment programmes or the widespread introduction of online cash registers. Therefore, it was high time that the MNB undertook another survey about payment habits among Hungarian companies and retailers after similar surveys conducted earlier. In addition, there are issues, such as the factors influencing card acquiring, where the analyses of the detailed online cash register (OCR) database covering a broad range of the retail transactions ${ }^{1}$ enable a more robust examination of the retail sector for factors that cannot be surveyed. The paper also utilises this database, thereby supplementing the surveys that contain partly differing information.

This study takes an in-depth look at the following main research questions, before drawing public policy conclusions of practical relevance: 1) What characterises the payment habits of Hungarian companies and retailers, and are there any differences between the two groups or between this and similar surveys conducted earlier? 2) What characterises the financial awareness and knowledge of the two target populations regarding instant payment, the (banking) costs of payments, and can subgroups be identified that can use electronic payment solutions at a much higher price? 3) What characterises the Hungarian card acquiring network, and which factors influence card acquiring and cash use? In examining the data, general statistical correlations are identified, and the factors influencing card acquiring and cash payments are analysed with a decision tree and regressions to identify the main influencing factors as accurately as possible. Section 2 presents the findings in the literature so far, while Section 3 details the data and the methodology. Based on the data, the maturity of the acquiring network and transaction figures are presented in Sections 4 and 5. Section 6 summarises the questions on financial awareness that influence the choice between the various payment methods. Finally, Section 7 provides a summary and conclusions.

\footnotetext{
${ }^{1}$ Taxpayers can only fulfill their obligation of giving receipt with online cash register for certain activities.
} 


\section{Overview of the literature}

Several studies have dealt with payment habits, but most of these have explored consumer choices, and therefore their results can only be used in this analysis for the retail segment and only to a limited extent. Polish surveys show that, although consumers are typically aware of electronic payment methods, consumer habits can only be changed slowly and with the advantages related to a particular form of payment (Harasim - Klimontowicz 2013; Dahlberg - Öörni 2008). This hinders the widespread adoption of electronic payment methods, since retailers often reject these new payment options due to the expected low transaction volume. A Dutch consumer survey (Jonker et al. 2018) showed that the switch from cash transactions to card payments depends largely on consumers' income and the value of the purchase, and it is more typical among businesses with a non-retail main activity.

In several countries, not only consumer surveys but also studies focusing specifically on businesses were conducted. The analysis of Finnish companies and retailers by Leinonen (2008) showed that electronic payments exceeded cash by far in the case of companies, and respondents expected a further increase in this respect. Another interesting finding was that in this segment the use of electronic payments is strongly influenced by the delivery channels offered by payment service providers to their corporate customers, and how these can be integrated into accounting and bookkeeping systems. However, for retailers the most important aspect is the speed (real time) and simplicity of financial transactions. This explains why cash use is so dominant in this sector, although it should be noted that several regulatory measures have been introduced on the card market since the survey to increase competition, and instant payment solutions have also become available. Gresvik and Haare (2007) examined transactions at physical points of sale. According to their results, the share of cash transactions was below 50 per cent in the Nordic countries more than ten years ago, and in the latest survey focusing on Danish B2B payments cash transactions were not even represented, as they were deemed so insignificant (The Danish Payments Council 2019). In other countries with a rather cash-intensive payments market, card acquiring is typically in line with the size of the retailer and is much more frequent at larger retailers, as pointed out by a survey of Canadian retailers (Kosse et al. 2017). Loke (2007) also reached similar conclusions while examining the Malaysian market, where - in addition to the volume of transactions - the specific retail segment was also decisive in the decision on retailers' card acquiring. Bounie et al. (2017) compared retailer and household surveys in an analysis of the French market, with a special emphasis on network effects, finding that card acquiring is influenced to a large degree by consumer 
preferences between methods of payments, in other words the extent of customer demand for card payments.

The Hungarian situation was analysed by Turján et al. (2011), primarily from the perspective of the costs related to the different payment methods, while Takács (2011) and Ilyés - Varga (2015) looked at payment habits in the household sector, finding a major dominance of cash use. Focusing on card acquiring by retailers, Ilyés - Varga (2018) used the online cash register database of the National Tax and Customs Administration (NTCA) to show a massive dominance of cash in retailer payments, and it was found that according to data from 2016, the size of the business was the most important explanatory variable of card acquiring. Earlier analyses also confirmed that there are large differences across the various regions in terms of retailer card acquiring, which is less typical in the eastern part of the country and in smaller settlements (Kajdi-Nemecskó 2020). In her study using both qualitative and quantitative methods, Bódi-Schubert (2014) specifically focused on small and medium-sized enterprises. It was found that while B2B payments were clearly dominated by credit transfers, cash use was still frequent, which was mainly justified by respondents with a lack of confidence and the desire to avoid any gridlock. A later survey also including microenterprises (Belházyné et al. 2018), arrived at similar conclusions regarding the distribution of payment methods, but cash use was attributed to the established habits among partners rather than a lack of confidence. This study also confirmed that cash use decreases with a growth in company size.

\section{Data and methodology}

This study uses the data from two questionnaire-based surveys and the online cash register database available to the MNB as provided by the NTCA. The MNB commissioned Kutatópont $\mathrm{Kft}$. to conduct two separate questionnaire-based surveys between December 2019 and January 2020 for the data describing 2019 in the retail sector and for the corporate sector with other activities. The sample size of successful responses (providing actual answers) in both surveys included 300 businesses. The corporate sample mostly contained service providers (vehicle repairs, real estate brokering, transportation), production companies (manufacturing of furniture and clothes) and building and construction firms (construction of roads and residential buildings). The corporate data were assigned weights and grossed up using the publicly available Hungarian Central Statistical Office (HCSO) data by region, main activity and headcount category. 
The questionnaire-based retailer database includes businesses whose main activity is retail trade, and in their case the online cash register database taken over from the NTCA was also utilised during the weighting and grossing up. This meant 50,837 taxpayers with retail trade as their main activity, and based on this, the data are representative by region, transaction volume and main activity (NACE groups 47). The retailer sample only took into account retailers with a gross annual sales revenue of less than HUF 1 billion, excluding those above this figure, which are typically retail chains. The questionnaires could be filled out in person, over the phone or online. Since detailed data on financial management and finances had to be provided, the interviewers usually turned to firms' controlling departments. The questions spanned from specific data (e.g. distribution of incoming and outgoing payments by payment methods, banking costs, wage costs and the method of wage payment, headcount) to attitude-type questions, which were mainly suitable for assessing financial awareness and taking stock of plans for future developments.

Due to the small sample size, the analysis only presents the main descriptive data and distributions, supplemented by analyses examining the explanatory variables influencing cash use by consumers and the card acquiring service in more detail. The main explanatory variables were identified using the decision tree method based on machine learning, as well as regressions based on the statistical approach, which better describe the partial effect of explanatory variables. The logistic model was used in the analysis of card acquiring, while the Heckman selection model was employed in the examination of cash use, as this model addresses the selection effect caused by the stores accepting cards and those not accepting them.

Along with the survey data, online cash registers' retail information from 2019 was also evaluated with the same methodology to check the results of the analyses of the retail surveys and to add new analysis aspects, filtering out the data from the taxpayers with an annual sales revenue of over HUF 1 billion, a typical threshold for retail chains. Due to the large sample size, the analyses of the OCR database are more robust, as they contain all the receipt and simplified invoice data of retailers required to use online cash registers. The cash register data are also anonymous, but the transactions related to individual taxpayers, taxpayers' main activity and the actual place of the transaction at the level of districts can be identified using IDs. As the OCR database contains data broken down to the district level, the information does not clearly identify stores, and therefore the analysis used the aggregate data from taxpayers' so-called retail units that are engaged in the same activity in 
a district. ${ }^{2}$ In the case of OCR data, information identical to that contained in the questionnaire (taxpayers' annual revenue, region, NACE code of the main activity) was examined, as was the revenue and lifetime of stores, which allowed conclusions to be drawn as to differences between stores that were open all year long and those that were opened during the year. Further aspects included stores' activity, which is the ratio between the number of days when the store was open and lifetime, representing whether a store was open every day or perhaps only on a few days, and also the number of transactions in stores.

With respect to retailers' NACE activity, it should be noted that taxpayers' main activity may not reflect the actual business activity. Another difference between the retail questionnaire data and the online cash register database is that while in the case of the former the distribution of revenue across units cannot be broken down by stores, and therefore taxpayers' card acquiring is examined, in the case of online cash register data, taxpayers' data broken down by activity are aggregated at the district level, and these units can also be observed. With regard to territorial distribution, while the questionnaire data show taxpayers' registered location, the cash register database contains the actual place of transactions, which, however, does not influence representativeness.

\section{Level of development of the card acquiring network}

According to the survey, most retailers and companies have a single sales unit in the country, and just 3 per cent of retailers have more than two sales units, while the same ratio is 9 per cent for businesses. The number of sales units for mediumsized and larger enterprises varies between 1 and 23. In the case of companies, the sectors cannot be examined separately by NACE code due to the small sample size, but it must be borne in mind that firms may differ significantly. For example, while a construction firm probably has fewer sales units but a larger turnover, and card acquiring is not relevant, a transportation company or a vehicle repair network may

\footnotetext{
${ }^{2}$ Unit refers to a single store if the given taxpayer has only one store engaged in the same field of activity within the same district, or the aggregate data when there are multiple such stores. Therefore, the number of units is lower than the number of actual stores, while the amount of revenue or the number of transactions per unit may be higher than the actual figures. This can influence the two main characteristics under review, namely card acquiring and cash use if the given taxpayer has several stores engaged in the same activity in the same district. If all the stores accept cards, this distorts the proportion of card acquiring stores downwards, while it distorts the figure upwards if only non-acquiring stores are aggregated. If there are both acquiring and non-acquiring stores, the unit comprising them is represented as card acquiring. In this case, if the proportion of the card acquiring stores is larger than the original card acquiring rate, this distorts stores' card acquiring rate downwards, or when it is smaller, it does so upwards. As shown later, the questionnairebased data confirm the hypothesis that the stores not offering card payments are almost exclusively those belonging to the largest group of the smallest businesses with a single sales unit. Therefore, there are probably only a few cases when only non-acquiring stores are aggregated, so the upwards distorting effect arising from this is only minor, if it exists at all. The distortion arising from aggregating only acquiring stores or those that include both acquiring and non-acquiring ones is also presumably small, as according to the questionnaire just 3 per cent of retailers have more than two sales units. As regards the cash use ratio, since a unit's transactions also include those of non-acquiring stores, the cash use ratio examined in acquiring stores may distort the outcome upwards, making it higher than the actual figure.
} 
have several sales units, with lower turnover each, and in their case card acquiring is relevant and usually offered. Card payments are possible at about 40 per cent of companies, and where card acquiring is present, all sales units offer this. In the case of retailers, on average 71 per cent of the almost 65,000 sales units provide an option for card payment, and non-acquiring stores are almost exclusively those belonging to the largest group of the smallest businesses with a single sales unit. According to OCR data, card payments are offered in 58 per cent of retailers' almost 60,000 sales units.

The survey also examined card acquiring through qualitative questions, allowing respondents which only offer cash payments to mark several options as to why they do not offer card payments. In the case of non-retail companies, the most dominant factor was that customers did not demand it (61 per cent). In the case of a large portion of companies, their products are presumably purchased by retailers or even other companies in large quantities for further selling or use, or their main activity is construction or production, so in their case card acquiring is not relevant. Other major factors include high POS terminal and banking costs, with 20 per cent of the companies ticking each of these answers. In the case of retailers, the main argument was also that customers do not need the card payment option, with 62 per cent of non-acquiring businesses reporting this. The costs associated with card acquiring were also an important factor (high bank fees: 48 per cent, expensive POS terminals: 29 per cent) and the low speed of card purchases (21 per cent). In addition, around 20 per cent of respondents said that they had already tested card acquiring but without success.

In the OCR database, the annual revenue of the commercial unit, the annual revenue of the taxpayer, the average value of purchases, the number of transactions, NACE codes and the lifetime and activity of the store all showed a significant correlation with card acquiring. No major difference was observed when examining the regions. ${ }^{3}$

The factors influencing card acquiring by retailers and companies were examined with a decision tree and logistic regression as well, so that the effect of explanatory variables on each other and any external influencing factors could be excluded to see which factors have the largest impact on the dependent variable under review. The decision tree based on machine learning can be used to identify the factors that make it easiest to decide whether a specific retailer or company is a card acquirer in the particular case under review. In addition, logit regression is a statistical method that enables the quantification of the partial effects and significance of explanatory variables, in other words whether the explanatory variables under review truly

\footnotetext{
${ }^{3}$ A more detailed description of the variables can be found in the discussion on the regression variables. Due to reasons of brevity, this study does not expound more on these basic statistics, but as can be seen below, the relationship between turnover and card acquiring, which is the most important variable, is presented in more detail in the Payment Systems Report. The 2019 data were discussed in the 2020 issue: https:// www.mnb.hu/letoltes/payment-systems-report-2020.pdf.
} 
have a significant impact, and if so, what the direction and extent of the resulting change is in the probability of card acquiring. The elements on the decision tree show the share of acquiring units within the group under review (upper value in the bubble), and the percentage of the group under review in the total population (lower value in the bubble). They also demonstrate that the variables shown are the explanatory variables that influence the dependent variable the most, and the classification into homogenous groups is undertaken along these lines.

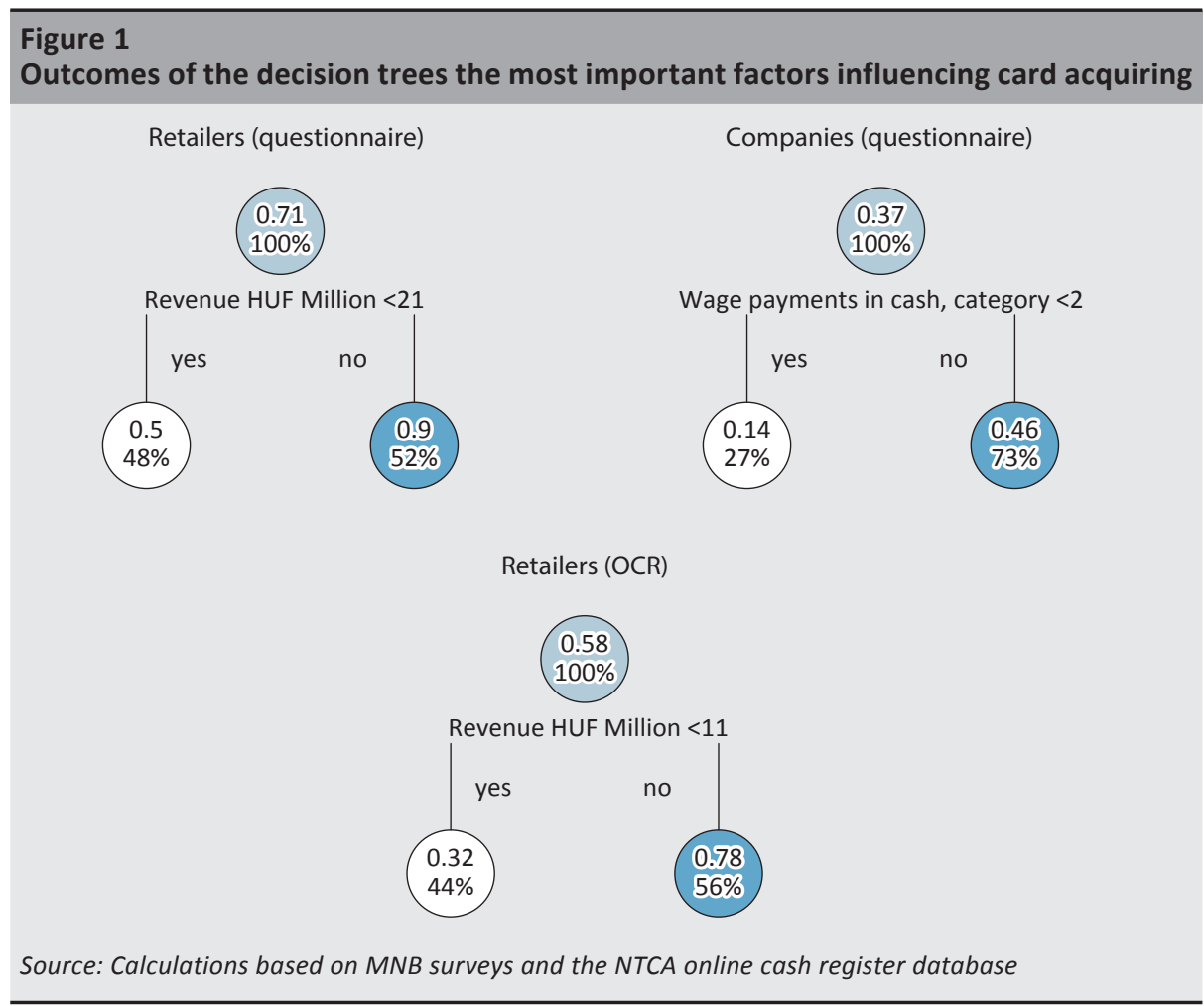

According to the decision tree based on the data from the retailer questionnaires, card acquiring is influenced the most by annual sales revenue (Figure 1). 71 per cent of retailers accept cards, and 90 per cent of retailers with annual sales revenue of at least HUF 21 million accept cards, while only 50 per cent of those with sales revenue below that do so. It should be noted that an annual sales revenue of HUF 21 million amounts to less than HUF 2 million per month, which is a low value in nominal terms, in other words a quite high share of card acquiring can be observed among retailers, even at a relatively low revenue level. In the case of companies, sales revenue was less dominant in card acquiring, due to the sectoral differences mentioned in the previous section. According to the decision tree, card acquiring was influenced the most by the share of cash wage payment. The share of cash wage payment is a categorical variable, it takes a value of 1 if 100 per cent of wages are 
paid in cash, 2 for $56-99$ per cent, 3 for $45-55$ per cent, 4 for $1-44$ per cent and 5 for 0 per cent. Companies that pay 100 per cent of all wages in cash are typically not acquirers, as only 14 per cent accept card payments. This is probably attributable to the sectoral difference presented in Section 3. Companies that typically pay wages by credit transfer are more likely to be card acquirers ( 46 per cent). The results from the decision tree prepared for the online cash register database are consistent with the questionnaire-based survey in that card acquiring is influenced the most by the annual revenue of retail units. Based on data from 2019, 58 per cent of the commercial units of the retail companies observed from the database are acquirers, and within that 78 per cent of the units with annual revenue of at least HUF 11 million (less than HUF 1 million per month) are acquirers, and in the case of the stores with revenues below that 32 per cent offered card payments in 2019 (comprising 44 per cent of the total sample). The examination of the decision trees for the previous years shows that the acquiring rate increases over time, and within that the amount of annual revenue steadily diminishes across the breakdown into homogenous groups, which means that card acquiring is more and more common even among the units with lower annual revenues.

By adjusting for the various effects using logistic regression (correlation of explanatory variables, endogeneity issues), we can examine whether the different explanatory variables actually impact the dependent variable (whether they are significant), and if so, what the direction of their impact is. Similar to the decision tree, the value of a logistic regression's dependent variable is 1 if the given retailer or company is card acquiring, and 0 if it is not. The regression uses regional features as explanatory variables, since the probability of card acquiring may differ across the regions with varying levels of economic development. The factors describing the income position and payment habits of retailers and companies are also explanatory variables, as the variables related to size category and payment habits strongly influence card acquiring based on the decision tree. The explanatory variables can be used to analyse complex effects regarding card acquiring. Table 1 shows the odds ratios of the logistic regression employed for the retailer and corporate questionnaires and the online cash register database. If the odds ratio of a given explanatory variable is below 1 , that reduces the probability of card acquiring, while if it is above 1 , then it increases the probability. In the models shown in the table, a significant impact was observed for all explanatory variables at the 95 per cent confidence level that was examined.

When analysing card acquiring by retailers and companies, the explanatory variable for cash wage payment was ultimately included in the model as a dummy variable to ensure homogeneity: above 55 per cent retailers and companies were deemed mostly cash paying, while those below it were deemed mainly non-cash paying. From a territorial aspect, large regions should be examined rather than regions. 
The following equation was written for the logistic regressions of corporate questionnaire data:

$$
\begin{gathered}
y=\beta_{0}+\beta_{1} \ln (\text { Sales revenue })+\beta_{2} \text { Large region }+\beta_{3} \text { Settlement type }+ \\
\beta_{4} \text { Number of sales unit }+\beta_{5} \text { Cash wage payment }+\beta_{6} N A C E+\varepsilon
\end{gathered}
$$

In the case of retailers, settlement type was not significant $\left(\beta_{3}=0\right)$, while in the case of companies the NACE codes were excluded from the final model $\left(\beta_{6}=0\right)$ due to the small sample size and the wide range of fields of main activity.

In the equation:

- dependent variable:

$-\mathrm{y}$ : whether the retailer or company is card acquiring ( 0 or 1 )

- explanatory variables:

- logarithm of annual gross sales revenue

- large region code (Central Hungary, Transdanubia, Great Plain and North)

- settlement type: (Budapest, city with county rights, city, municipality)

- number of sales units

- cash wage payment ( $0=$ wages mainly paid in a form other than cash, $1=$ wages are mainly paid in cash)

- NACE: ${ }^{4}$ main activity of the respondent

Due to the different data structure of the online cash register database, the equation of the logistic regression for it differs from the previous one:

$$
\begin{gathered}
y=\beta_{0}+\beta_{1} \ln (\text { Sales revenue })+\beta_{2} \text { Number of transactions }+ \\
\beta_{3} \ln (\text { Average purchase value })+\beta_{4} \text { Lifetime }+\beta_{5} \text { Activity }+\beta_{6} N A C E+\varepsilon
\end{gathered}
$$

In the equation:

- dependent variable:

$-\mathrm{y}$ : whether the retail unit is card acquiring ( 0 or 1 )

- explanatory variables:

- logarithm of annual gross sales revenue of the retail unit ${ }^{5}$

- number of transactions at the retail unit in the given year

- logarithm of the average value of transactions at the retail unit ${ }^{6}$

- lifetime of retail unit (number of days between the first and last transaction in the year)

- activity of the retail unit (number of days with actual transactions/lifetime of the store)

- NACE: main activity of the taxpayer

${ }^{4}$ Uniform Classification of Economic Activities, 2008

${ }^{5}$ The annual revenue of the retail unit and the taxpayer were both examined, and the revenue of the store was a better fit for the model.

${ }^{6}$ The average purchase value was calculated as the ratio of annual revenue and the annual number of transactions. 


\section{Table 1}

Results of the logistic regressions for corporate and retailer card acquiring (odds)

\begin{tabular}{|c|c|c|c|}
\hline Variable & Companies & Retailers & $\begin{array}{l}\text { Retailers } \\
\text { (OCR) }\end{array}$ \\
\hline Logarithm of sales revenue & $\begin{array}{c}1.12^{*} \\
(87.34)\end{array}$ & $\begin{array}{c}2.65^{*} \\
(73.50)\end{array}$ & $\begin{array}{c}2.52^{*} \\
(-90.72)\end{array}$ \\
\hline Number of transactions & - & - & $\begin{array}{l}1.00 * \\
(-9.61)\end{array}$ \\
\hline Logarithm of average purchase value & - & - & $\begin{array}{l}1.08^{*} \\
(5.93)\end{array}$ \\
\hline Lifetime & - & - & $\begin{array}{c}0.99 * \\
(-0.01)\end{array}$ \\
\hline Activity & - & - & $\begin{array}{l}1.85^{*} \\
(0.62) \\
\end{array}$ \\
\hline \multicolumn{4}{|l|}{ Large region (Central Hungary) } \\
\hline Transdanubia & $\begin{array}{c}0.87^{*} \\
(-24.66)\end{array}$ & $\begin{array}{l}1.16^{*} \\
(4.49)\end{array}$ & - \\
\hline Great Plain and North & $\begin{array}{c}0.77, * \\
(-43.68)\end{array}$ & $\begin{array}{c}0.51^{*} \\
(-21.29)\end{array}$ & - \\
\hline \multicolumn{4}{|l|}{ Settlement type (Capital) } \\
\hline City with county rights & $\begin{array}{c}1.28^{*} \\
(38.50)\end{array}$ & - & - \\
\hline City & $\begin{array}{c}0.69 * \\
(-63.48)\end{array}$ & - & - \\
\hline Municipality & $\begin{array}{c}0.72 * \\
(-40.86) \\
\end{array}$ & - & - \\
\hline \multicolumn{4}{|l|}{$\begin{array}{l}\text { Hungarian NACE Rev. } 2 \text { (471: Retail sale in non- } \\
\text { specialised stores) }\end{array}$} \\
\hline $\begin{array}{l}472 \text { (retail sale in specialised stores, e.g. } \\
\text { butchers, bakery, tobacco store, grocery shop) }\end{array}$ & - & $\begin{array}{c}0.46^{*} \\
(-18.47)\end{array}$ & $\begin{array}{l}0.93^{*} \\
(-2.05)\end{array}$ \\
\hline 473 (automotive fuel) & - & $\begin{array}{l}1.00 * \\
(0.00)\end{array}$ & $\begin{array}{c}0.54^{*} \\
(-4.86)\end{array}$ \\
\hline $\begin{array}{l}474 \text { (IT, consumer electronics, } \\
\text { telecommunication) }\end{array}$ & - & $\begin{array}{c}0.44^{*} \\
(-10.40) \\
\end{array}$ & $\begin{array}{l}1.21^{*} \\
(2.70)\end{array}$ \\
\hline $\begin{array}{l}475 \text { (other household equipment, e.g. textiles, } \\
\text { furniture, small electrical appliances) }\end{array}$ & - & $\begin{array}{c}0.28^{*} \\
(-27.95)\end{array}$ & $\begin{array}{c}0.54^{*} \\
(-14.46)\end{array}$ \\
\hline $\begin{array}{l}476 \text { (culture, recreation: books, newspapers, } \\
\text { sports equipment, games and toys) }\end{array}$ & - & $\begin{array}{c}1.86^{*} \\
(11.50)\end{array}$ & $\begin{array}{l}1.67^{*} \\
(9.29)\end{array}$ \\
\hline $\begin{array}{l}477 \text { (clothing, footwear, pharmaceuticals, } \\
\text { perfumery) }\end{array}$ & - & $\begin{array}{c}0.44^{*} \\
(-21.87)\end{array}$ & $\begin{array}{c}0.93^{*} \\
(-2.52)\end{array}$ \\
\hline 478 (stalls and markets) & - & $\begin{array}{c}0.13^{*} \\
(-43.33)\end{array}$ & $\begin{array}{c}0.53^{*} \\
(-8.14)\end{array}$ \\
\hline $\begin{array}{l}479 \text { (sales not in stores, mail order houses, } \\
\text { internet) }\end{array}$ & - & $\begin{array}{c}0.19 * \\
(-29.83)\end{array}$ & $\begin{array}{c}0.4^{*} \\
(-15.67)\end{array}$ \\
\hline Number of sales units & $\begin{array}{c}3.48^{*} \\
(216.40)\end{array}$ & $\begin{array}{c}4.25^{*} \\
(12.82)\end{array}$ & - \\
\hline Cash wage payment & $\begin{array}{c}0.23^{*} \\
(-307.21) \\
\end{array}$ & $\begin{array}{c}0.51^{*} \\
(-25.57) \\
\end{array}$ & - \\
\hline Constant & $\begin{array}{c}0.18^{*} \\
(-201.85) \\
\end{array}$ & $\begin{array}{c}0.12^{*} \\
(-17.25)\end{array}$ & $\begin{array}{l}-14.07^{*} \\
(-90.72)\end{array}$ \\
\hline $\mathbf{R}^{2}$ & 0.12 & 0.3 & 0.3 \\
\hline$N$ & 300 & 300 & 57,848 \\
\hline
\end{tabular}

Note: * Coefficients significant at the 95 per cent confidence level, with the values of the z-tests in brackets Source: Calculations based on MNB surveys and the NTCA online cash register database 
Based on the regression results from the data of the questionnaire, the probability of card acquiring increases with the size of business: card acquiring is positively correlated with the sales revenue of retailers and companies, as is the case with the number of sales units; in other words, the bigger the firm is, the more likely that it offers customers this type of payment method, which is consistent with the findings of Loke (2007) and Kosse et al. (2017) and the earlier analysis of the situation in Hungary by llyés - Varga (2018).

In terms of regions, the probability of card acquiring is typically lower in the two large regions other than Central Hungary. The exception to this is Transdanubia in the case of retailers, which is attributable to the vibrant tourism and retail sector in the large region, and to the fact that only retailers with annual sales revenues under HUF 1 billion were included in the sample. Card acquiring is the lowest at both retailers and companies in the large region containing the Great Plain and Northern Hungary. In terms of settlement type, city with county rights, boast a significantly higher probability of card acquiring than Budapest, while municipalities have a lower probability. The regional card acquiring data are consistent with the earlier results of Kajdi-Nemecskó (2020).

At companies, wages are mostly paid through credit transfer, but cash wage payments have a negative effect on the probability of card acquiring. At retailers and companies where outgoing payments (e.g. wages) are mostly conducted in cash, incoming cash payments are probably preferred over card payments, which has a negative impact on card acquiring.

Based on the examination of main activities, retailers can also be segmented from the perspective of card acquiring: similar to non-specialised retailers, the probability of card acquiring is high at petrol stations and in the field of culture (newsagents, bookshops), but there is still considerable room for improvement among retailers selling via stalls and markets, and smaller specialised retailers.

The regression using online cash register data also confirms the positive correlation between the sales revenue of retail units and card acquiring.

As regards the fields of activity, the results are almost always the same as with the questionnaire, but in the case of stores with fields of activity related to automotive fuel and IT, consumer electronics or telecommunication, the cash register data shows the opposite as compared to the reference activity: in the case of automotive fuel, the probability of card acquiring is lower, rather than the same, as compared to retail sales in non-specialised stores, while the probability is higher at stores with a field of activity related to IT, consumer electronics or telecommunication. This difference may be attributable to the small sample size of the questionnaire. When interpreting the results, it must be borne in mind that the NACE code under 
review indicates the reported main activity of the taxpayer, which may differ from the actual field of activity.

Although Loke (2007) also found that the field of activity of the retailer influences the probability of card acquiring, she analysed this with a much simpler variable using three categories, and thus the results cannot be directly compared. In the case of the variables that differed from those used for the questionnaire, an additional piece of information is that the number of transactions, which has a very significant impact, reduces the probability of card acquiring, albeit only slightly, which reflects the refusal of stores selling many smaller-value items to accept cards.

Average purchase value is also positively correlated with card acquiring, in line with the results of earlier studies, namely that card payments are more typical in the case of items with a higher value, which therefore indirectly influences card acquiring.

The lifetime of the store has a negative impact, which may suggest that newly opened stores are typically card acquiring. As regards the activity of the store, the more days it is open during the week, the more likely that it accepts cards. Regional differences were examined here as well, although this did not become a significant variable in terms of card acquiring for this database, which may be explained by the distorting effect arising from the clear unidentifiability of the real stores as described above.

\section{Turnover data}

In the questionnaire-based survey, companies and retailers had to give a detailed account of their incoming and outgoing payments by number and value of transactions, broken down into different payment methods. This provides an opportunity to gain an accurate picture about the types of businesses where cash use dominates, and the method of incoming payments (received for the goods or services sold) and outgoing payments (to suppliers and employees) can also be identified, which supplements the OCR data.

Certain basic trends can be pinpointed in incoming payments. The payments to retailers are more typically made in cash than in the case of companies, with around 80 per cent of incoming payments conducted in this manner (Figure 2). This ratio is consistent with the results of the analyses of the online cash register database. With respect to the other countries in the region, the results presented here should be compared to those by Górka (2012) describing the Polish retail market. Górka's study showed almost 90 per cent cash use at physical points of sale. It should be noted, however, that cash use has probably also declined in Poland since that analysis was prepared. The latest survey of the European Central Bank (ECB 2020) on households' payment habits examined consumer habits rather than retailers, and 
it also found, indirectly, that similar ratios were seen in most European countries regarding retail payments, in other words cash still dominates in physical purchase situations. When examining the distribution by value at retailers or companies, it is found that the value of cash payments is lower, which is attributable to the relatively small number of large electronic transfers. Similar trends can be identified with outgoing payments.

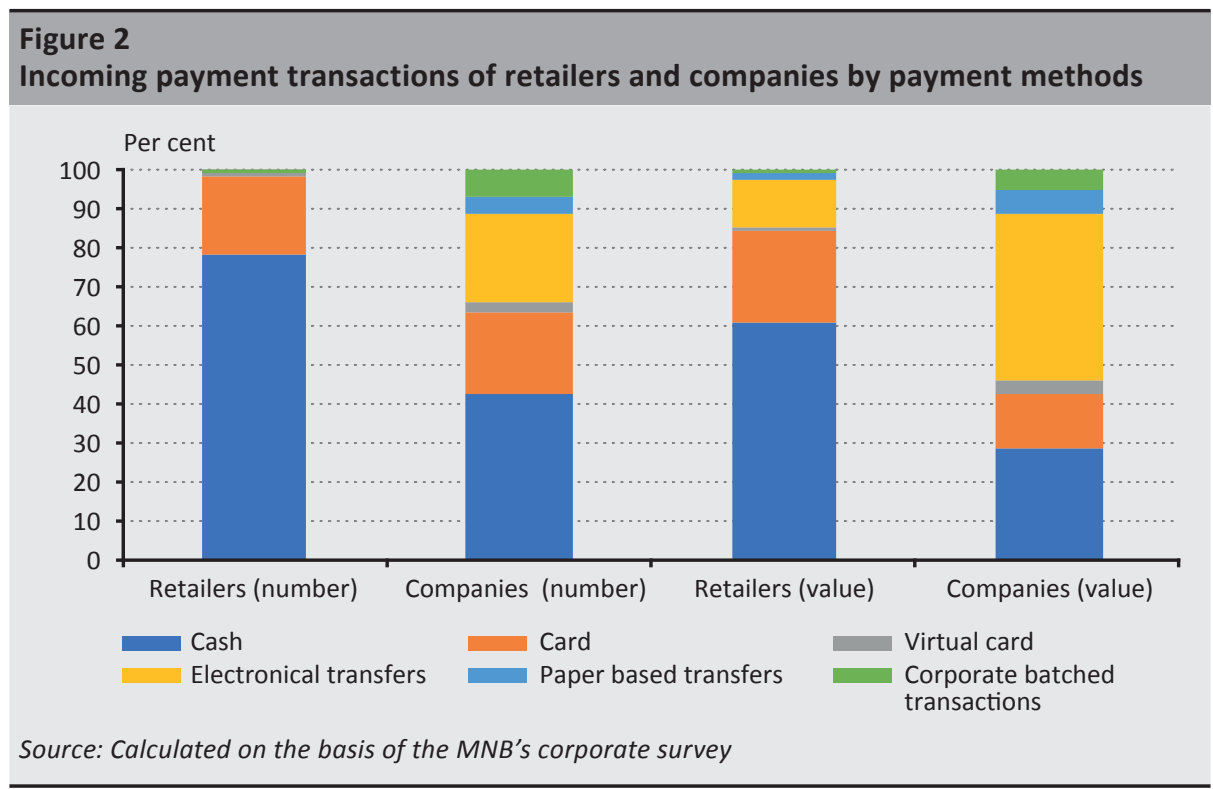

\subsection{Headcount category differences}

In analysing the corporate data, the sample was divided into groups by headcount category. Turnover data may vary widely across the different company sizes; the following categories were thus used: 0-9, 10-19, 20-49, 50-249, over 250 employees.

Based on the responses received, there seems to be a substantial difference between firms of different sizes in terms of the distribution by payment method of incoming transactions. While approximately 40-50 per cent of incoming payments are made in cash at smaller companies (with under 50 employees), the share of card payments and other forms of electronic payment is 20 per cent each (Figure 3). At larger companies, the ratio of cash payments has diminished, and in their case the ratios of cash payments, card payments (physical or online) and electronic transfers are more balanced (at 25, 35, 28 per cent, respectively). In the case of the largest companies (with 250+ employees), some 85 per cent of incoming payments 
are made via electronic transfer, with only a small share remaining for the other payment methods. Examining the value of incoming payments, similar trends can be observed, but the share of electronic transfers is even higher. The results presented here are therefore consistent with the correlations identified between cash use and company size in Belházyné et al. (2018).

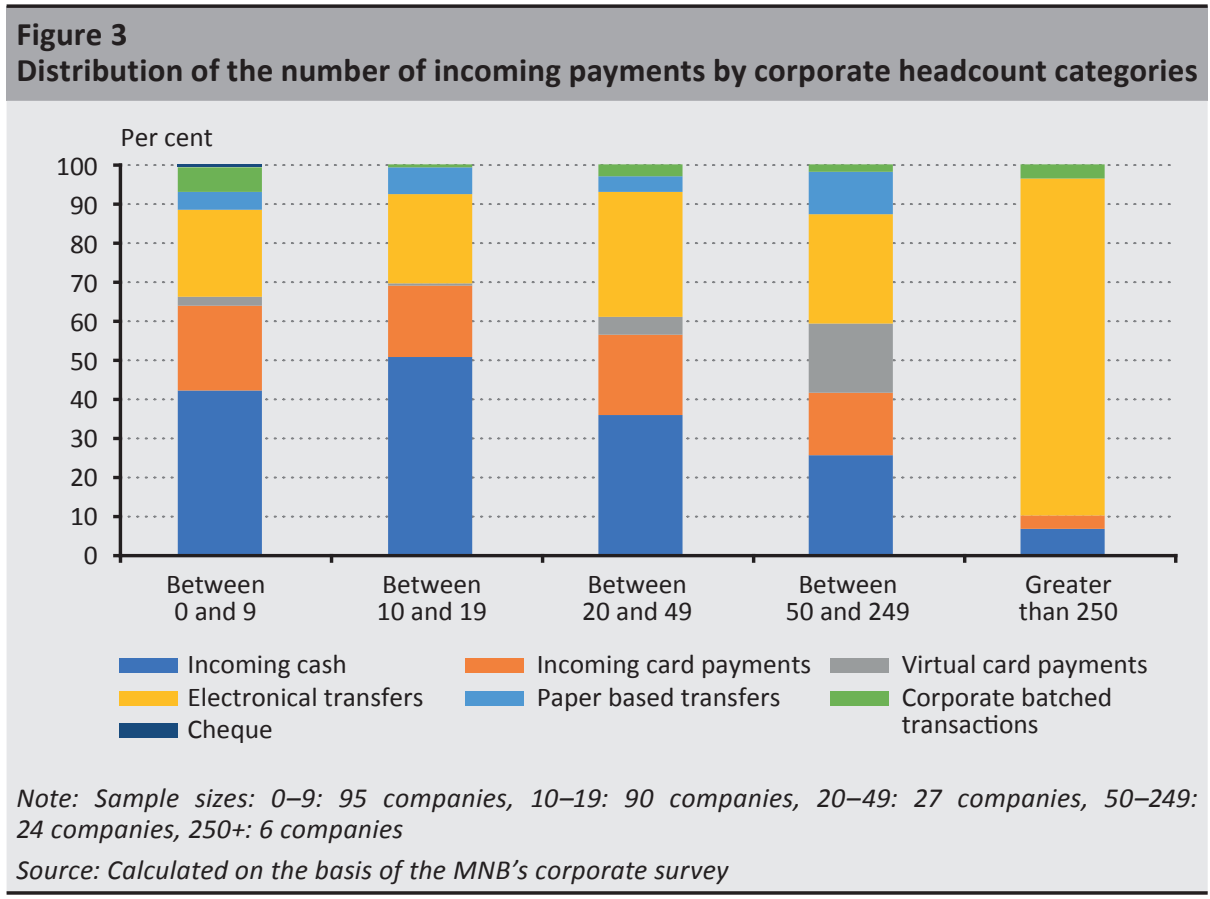

On the whole, electronic payment methods are widespread among companies. Looking forward, the reduction of cash transactions should be an important objective mainly in the case of the firms with less than 50 employees.

Turnover in the different payment methods was examined for retailers as well, but with some differences. First, the number of retailers with a lower headcount is much higher, so the bottom category was divided further, and no retailer with a headcount of over 50 was included in the sample. Second, only cash, card and other payment methods were distinguished for incoming payments in retail sales. In this segment as well, the share of electronic (card) payments increases with size: while over 90 per cent of payments were made with cash in the smallest category, this figure fell to 60 per cent in the largest category (Figure 4). 


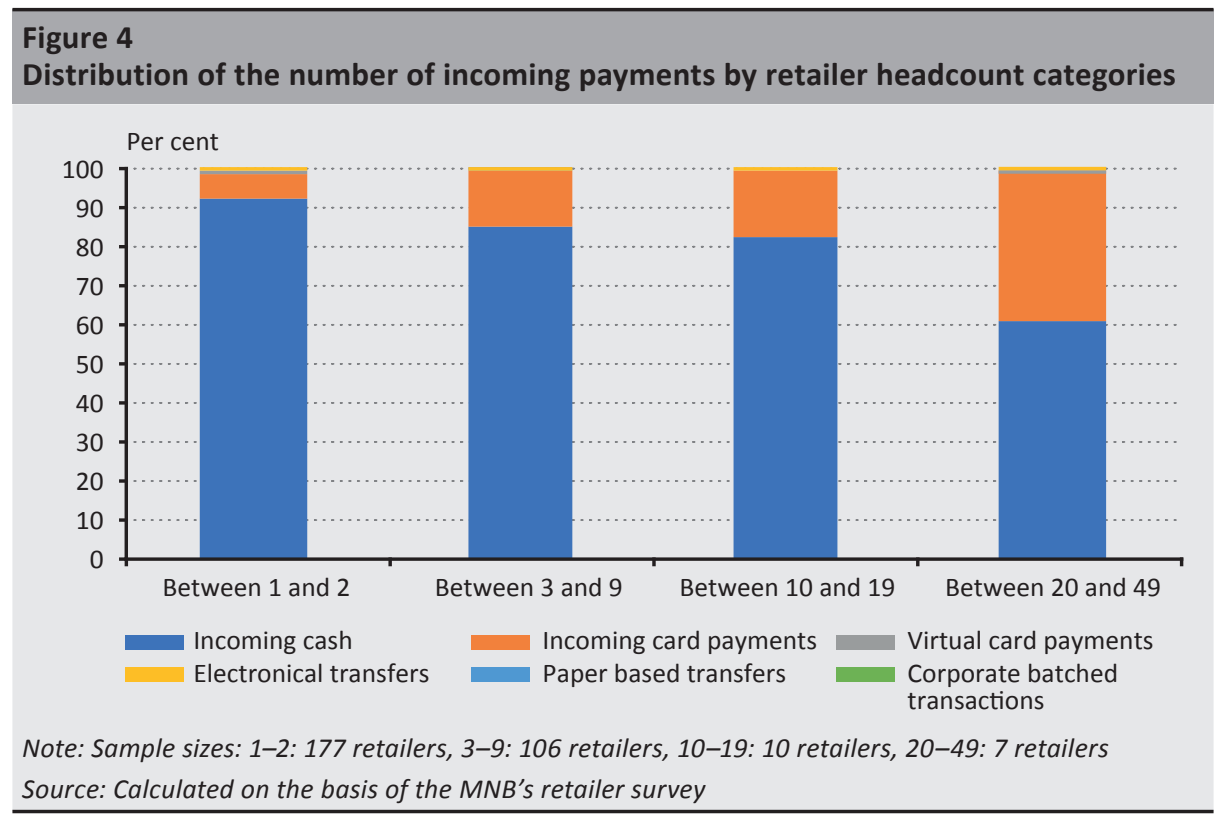

In the analysis by the value of incoming payments, retailers also typically accept credit transfers, with this ratio at below 20 per cent at firms with less than 10 employees and at around 30-35 per cent at larger retailers. The data show that credit transfers are not widespread in the retail sector, and only a few large transactions are conducted in this manner. If only card acquiring retailers are considered, the situation also does not change much as regards the number of transactions or the distribution by value. This shows that the (cash) turnover of the retailers that do not offer card payments is relatively marginal from the perspective of the sector as a whole, and this also holds true for the retail units examined in the online cash register database. 


\subsection{Main factors determining cash use}

From a public policy perspective, it may be crucial to identify the factors that prompt companies to prefer cash use over electronic payment methods, since future regulatory measures and development projects in payments can be designed in a more targeted way using this information. First, a decision tree was prepared to pinpoint the key factors that determine the share of incoming cash within total turnover at acquiring stores. Then, the cause-and-effect relationships were explored using the Heckman selection model, which can be more readily interpreted for statistical purposes and also addresses the selection effect. In the latter case, the whole population was examined, and the two-stage regression model also handles the differences arising from card acquiring and non-acquiring.

Examination of the decision trees shows that based on the retail questionnaire, the factor with the largest impact on the share of incoming cash transactions in card acquiring stores is the proportion of cash wage payment, ${ }^{7}$ and the NACE code also has a more substantial effect on cash use than the rest of the factors (Figure 5). At retailers where the share of cash wage payment is high, the ratio of incoming cash payments is also higher. Based on corporate data, cash wage payment is the factor influencing cash use the most: in other words, at firms characterised by cash wage payment, the proportion of incoming cash transactions is also higher.

In the online cash register data, analysis of the ratio of incoming cash transactions in card acquiring stores shows that based on the decision tree the most homogenous groups can be created on the basis of the average purchase value, which is thus the key factor influencing the cash ratio. At card acquiring retail units, the share of incoming cash transactions is 81 per cent overall. If the average purchase value is below HUF 3,753 at a given retail unit, the cash payment ratio is typically 88 per cent (with 61 per cent of the stores belonging to this category), while if the average purchase value is above that, the cash payment ratio is 68 per cent. The units can be divided into further groups by a further breakdown of the average purchase value.

\footnotetext{
${ }^{7}$ The share of cash wage payment is a categorical variable, it takes a value of 1 if 100 per cent of wages are paid in cash, 2 for 56-99 per cent, 3 for 45-55 per cent, 4 for 1-44 per cent and 5 for 0 per cent.
} 


\section{Figure 5 \\ Decision tree results: most important factors influencing the proportion of incoming cash transactions}

Retailers (questionnaire)

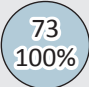

Wage payment in cash, category $>=2$

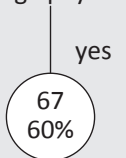

NACE codes $=473,476$

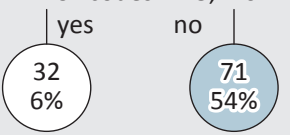

no

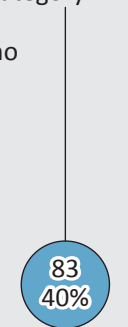

Companies (questionnaire)

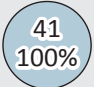

Wage payment in cash, category $>=2$

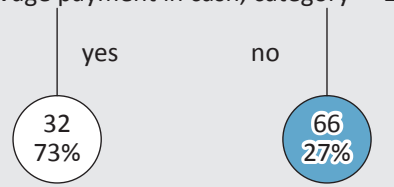

Retailers (OCR)
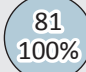

Average value of a transaction $>=$ HUF 3,753

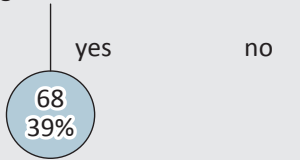

Average value of a transaction >= HUF 11,196

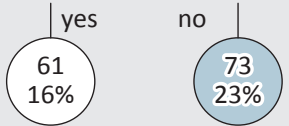

Linear regression was used to analyse the other factors that could impact the ratio of cash transactions. The regression only included acquiring retailers and companies, and therefore the potential selection bias was addressed with the Heckman correction. Since the dependent variable is constrained to values between 0 and 1 , a logit transformation of the cash use ratio is necessary in the regression, and thus the dependent variable is

$$
y=\ln [(\text { Cash ratio }+\mu) /(1-\text { Cash ratio }+\mu)],
$$

$\mu=0.00001$ constant (so the equation can be interpreted for a cash ratio of both 1 and 0 ). Therefore, the dependent variable can explain the evolution of the cash- 
non-cash ratio. The linear regressions for the retailer and corporate sample can be stated with the following equation:

$$
\begin{gathered}
y=\beta_{0}+\beta_{1} \text { Headcount category }+\beta_{2} N A C E+\beta_{3} \text { Online sales }+ \\
\beta_{4} \text { Ratio of outgoing cash payments }+ \text { Lambda }+\varepsilon
\end{gathered}
$$

In the case of companies, the NACE codes were excluded from this model as well, due to the small sample size and the wide range of fields of main activity. In the case of retailers, only those respondents were considered in the model that offer card acquiring. The similar models were examined on the basis of the value of cash transactions rather than the number of such transactions. This yielded similar results, but their explanatory power was weaker, so they are not included here.

In the equation:

- dependent variable:

$-y=\ln [($ Cash ratio $+\mu) /(1-$ Cash ratio $+\mu)], \mu=0.00001$ constant. Ratio of the number of cash transactions and non-cash transactions

- explanatory variables:

- headcount category of the respondent company

- NACE: main activity of the respondent

- binary (dummy) variable for online sales: 0 for no online sales, 1 for online sales

- proportion of cash transactions within all outgoing transactions (0-100 per cent)

- lambda (inverse Mills ratio)

Due to the structural difference of the online cash register database, the equation for the regression of it is as follows:

$y=\beta_{0}+\beta_{1}$ Region $+\beta_{2} N A C E+\beta_{3} \ln ($ Sales revenue $)+\beta_{4}$ Number of transactions + $\beta_{5} \ln ($ Average purchase value $)+\beta_{6}$ Store lifetime $+\beta_{7}$ Store activity + Lambda $+\varepsilon$

In the equation:

- dependent variable:

$-y=\ln [($ Cash ratio $+\mu) /(1-$ Cash ratio $+\mu)], \mu=0.00001$ constant. Ratio of the number of cash transactions and non-cash transactions among the transactions of retail units defined in the online cash register

- explanatory variables:

- region code, with Central Hungary including Budapest

- NACE: main activity of the taxpayer associated with the transaction

- logarithm of annual gross sales revenue of the taxpayer associated with the retail unit

- number of transactions at the retail unit in the given year (thousands)

- logarithm of the average value of transactions at the retail unit 
- lifetime of retail unit (number of days between the first and last transaction in the year)

- activity of the retail unit (number of days with actual transactions/lifetime of the store)

- lambda (inverse Mills ratio)

The results of the regressions are shown in Table 2. The cells contain the exponential power of the coefficients of the significant explanatory variables in the analyses of the databases indicated in the column, representing the extent of the change in the dependent variable for each unit of change, with the t-value in brackets. ${ }^{8}$

\section{Table 2}

Estimated coefficients of the linear regressions explaining cash use

\begin{tabular}{|c|c|c|c|}
\hline Variable & Companies & Retailers & Retailers (OCR) \\
\hline \multicolumn{4}{|l|}{ Headcount category (under 3 ) } \\
\hline Between 3 and 9 & $\begin{array}{c}0.27^{*} \\
(-161.78)\end{array}$ & $\begin{array}{c}0.22^{*} \\
(-47.94)\end{array}$ & - \\
\hline Between 10 and 19 & $\begin{array}{c}0.75^{*} \\
(-9.18) \\
\end{array}$ & $\begin{array}{c}0.20 * \\
(-37.71)\end{array}$ & - \\
\hline Between 20 and 49 & $\begin{array}{c}0.34^{*} \\
(-25.92)\end{array}$ & - & - \\
\hline Over 50 & $\begin{array}{c}0.12^{*} \\
(-32.26)\end{array}$ & - & - \\
\hline \multicolumn{4}{|l|}{ Regions (Central Hungary) } \\
\hline Northern Hungary & $\begin{array}{c}2.10^{*} \\
(52.96)\end{array}$ & - & $\begin{array}{l}1.64^{*} \\
(8.32)\end{array}$ \\
\hline Northern Great Plain ${ }^{8}$ & $\begin{array}{c}0.90 * \\
(-86.69)\end{array}$ & - & $\begin{array}{l}1.34^{*} \\
(5.61)\end{array}$ \\
\hline Southern Great Plain & $\begin{array}{c}1.34 * \\
(21.18) \\
\end{array}$ & - & $\begin{array}{l}1.33^{*} \\
(5.17) \\
\end{array}$ \\
\hline Central Transdanubia & $\begin{array}{c}1.25^{*} \\
(16.47) \\
\end{array}$ & - & $\begin{array}{c}0.81 * \\
(-3.52)\end{array}$ \\
\hline Western Transdanubia & $\begin{array}{c}0.86 * \\
(-10.77) \\
\end{array}$ & - & $\begin{array}{l}1.55^{*} \\
(7.18) \\
\end{array}$ \\
\hline Southern Transdanubia & $\begin{array}{c}0.84 * \\
(-37.47)\end{array}$ & - & $\begin{array}{l}1.37^{*} \\
(5.00)\end{array}$ \\
\hline \multicolumn{4}{|l|}{$\begin{array}{l}\text { Hungarian NACE Rev. } 2 \text { ( } 471 \text { : Retail sale in } \\
\text { non-specialised stores) }\end{array}$} \\
\hline $\begin{array}{l}472 \text { (retail sale in specialised stores, e.g. } \\
\text { butchers, bakery, tobacco store, grocery } \\
\text { shop) }\end{array}$ & - & $\begin{array}{c}2.36^{*} \\
(12.67)\end{array}$ & $\begin{array}{c}1.14 \\
(2.54)\end{array}$ \\
\hline 473 (automotive fuel) & - & - & $\begin{array}{l}3.06^{*} \\
(6.33) \\
\end{array}$ \\
\hline $\begin{array}{l}474 \text { (IT, consumer electronics, } \\
\text { telecommunication) }\end{array}$ & - & $\begin{array}{c}0.96 \\
(-0.38)\end{array}$ & $\begin{array}{c}0.56 \\
(-4.96)\end{array}$ \\
\hline
\end{tabular}

\footnotetext{
${ }^{8}$ Due to a large enterprise from the Northern Great Plain, the share of cash transactions may be lower in the region than in the Central Hungary region.
} 


\begin{tabular}{|c|c|c|c|}
\hline Variable & Companies & Retailers & Retailers (OCR) \\
\hline $\begin{array}{l}475 \text { (other household equipment, e.g. } \\
\text { textiles, furniture, small electrical } \\
\text { appliances) }\end{array}$ & - & $\begin{array}{l}1.43^{*} \\
(4.37)\end{array}$ & $\begin{array}{c}6.41 * \\
(23.24)\end{array}$ \\
\hline $\begin{array}{l}476 \text { (culture, recreation: books, } \\
\text { newspapers, sports equipment, games and } \\
\text { toys) }\end{array}$ & - & $\begin{array}{c}0.88 * \\
(-53.37)\end{array}$ & $\begin{array}{c}0.15^{*} \\
(-19.68)\end{array}$ \\
\hline $\begin{array}{l}477 \text { (clothing, footwear, pharmaceuticals, } \\
\text { perfumery) }\end{array}$ & - & $\begin{array}{c}2.16^{*} \\
(10.77)\end{array}$ & $\begin{array}{c}0.97 \\
(-0.63)\end{array}$ \\
\hline 478 (stalls and markets) & - & $\begin{array}{l}57.50 * \\
(29.74)\end{array}$ & $\begin{array}{c}8.05^{*} \\
(15.27)\end{array}$ \\
\hline $\begin{array}{l}479 \text { (sales not in stores, mail order houses, } \\
\text { internet) }\end{array}$ & - & $\begin{array}{c}4.29 * \\
(28.01) \\
\end{array}$ & $\begin{array}{c}6.57^{*} \\
(17.27)\end{array}$ \\
\hline Internet sales & $\begin{array}{c}0.81 * \\
(-12.23)\end{array}$ & $\begin{array}{c}0.70 * \\
(-44.20)\end{array}$ & - \\
\hline Share of the number of cash payments & $\begin{array}{c}1.11^{*} \\
(540.81)\end{array}$ & $\begin{array}{c}1.04 * \\
(53.84)\end{array}$ & - \\
\hline Logarithm of sales revenue & - & - & $\begin{array}{c}0.07^{*} \\
(-52.49)\end{array}$ \\
\hline Number of transactions & - & - & $\begin{array}{c}1.00 * \\
(-6.12)\end{array}$ \\
\hline Logarithm of average purchase value & - & - & $\begin{array}{c}0.46^{*} \\
(-37.16)\end{array}$ \\
\hline Store lifetime & - & - & $\begin{array}{c}1.01^{*} \\
(19.68)\end{array}$ \\
\hline Store activity & - & - & $\begin{array}{c}0.98^{*} \\
(-18.47)\end{array}$ \\
\hline Constant & $\begin{array}{c}0.01 * \\
(-142.13) \\
\end{array}$ & $\begin{array}{l}37.06^{*} \\
(45.08) \\
\end{array}$ & $\begin{array}{c}142.22 * \\
(69.28) \\
\end{array}$ \\
\hline Lambda $^{9}$ & $\begin{array}{c}0.05^{*} \\
(-50.45) \\
\end{array}$ & $\begin{array}{c}0.01 * \\
(-12.43) \\
\end{array}$ & $\begin{array}{c}0.02 * \\
(-25.08) \\
\end{array}$ \\
\hline $\mathrm{R}^{2}$ & 0.3 & 0.3 & 0.3 \\
\hline $\mathrm{N}$ & 113 & 187 & 33,020 \\
\hline
\end{tabular}

Note: * Coefficients significant at the 95 per cent confidence level, with the values of the $t$-tests in brackets Source: Calculations based on MNB surveys and the NTCA online cash register database

In the models prepared on the basis of questionnaire data, company size was taken into account through headcount categories. One general trend is that larger companies and retailers see lower levels of incoming cash transactions. In a regional comparison of companies, the proportion of cash transactions is lower in the more advanced Transdanubian regions (car industry), and higher in the Northern and Great Plain regions. A breakdown by main activity was only analysed for retailers: the lowest share of incoming cash payments was observed at retailers operating in

\footnotetext{
${ }^{9}$ The lambda parameter (inverse Mills ratio) is significant for all regressions, therefore the filtering for card acquirers includes selection bias, which required an adjustment.
} 
the IT and culture and recreation sectors, as well as those engaged in online sales. Online sales were examined separately with a dummy variable, and based on that the incoming cash turnover is also lower among companies that also sell online. A relationship was also detected with outgoing cash turnover, which may suggest that certain businesses prefer cash purchases because they have to make their outgoing payments in this manner.

Similar to the decision tree based on the online cash register database, the linear model also shows that the logarithms of sales revenue and average purchase value are the most important explanatory variables and are negatively correlated with the cash ratio. The regional variables have significant explanatory power here: compared to the benchmark of Budapest and Central Hungary, the cash use ratio is only lower in Central Transdanubia, while it is higher everywhere else. This may be related to the regional differences identified by Kajdi - Nemecskó (2020) regarding card use. When it comes to the fields of activity, compared to the benchmark of non-specialised retailers in stores, cash use is lower when the main activity of the taxpayer is in the IT, electronics or culture and recreation sectors, and almost the same or higher in the stores with other fields of activity. There was also variation based on the NACE code, which may be due to the small sample size in the questionnaire as mentioned before, and in interpreting the results it must be taken into account that the actual activity of the stores may differ from the registered main activity of the taxpayer.

\section{Financial awareness}

The choice between payment methods may be influenced by financial awareness, in particular the costs related to the different methods. This section describes the answers of companies and retailers to questions pertaining to this aspect in the questionnaire-based surveys. Most of this information comprises data on the costs of payment, i.e. the fees associated with providing cash-based and electronic payment methods. Moreover, several questions related to future development plans, in particular the introduction of instant payments in Hungary.

\subsection{Cash use}

In the case of firms, end-of-day cash holdings increase with size, while no such straightforward trend can be observed for retailers. In line with the turnover data, smaller companies record more cash transactions, while larger enterprises have an almost negligible amount of cash transactions. Smaller companies are characterised by cash withdrawals, while larger ones are characterised by cash deposits. This suggests that smaller firms have a stronger demand for cash and take out in cash the revenue received via credit transfer to cover their cash expenses. As presented in the analysis of turnover data, larger companies are characterised by 
a low proportion of cash transactions, so they typically deposit the cash received to their bank account, supporting their online turnover, which has a greater volume. In the case of retailers, no clear-cut link to growth in headcount could be established. At the same time, retailer data show that the value of cash deposits usually exceeded withdrawals. This is probably because cash is more typical in the incoming transactions of smaller retailers anyway, which allows them to satisfy their demand for cash in this manner.

Companies typically pay their employees' wages via credit transfer. Looking at small enterprises, 35 per cent of them pay wages in cash, while larger ones do not do this at all. As presented above, a large portion of smaller firms' cash transactions are conducted in cash (Figures 2, 3, 4), which is consistent with the fact that they pay some of their wages in cash. Out of the companies that pay wages not only via credit transfer, 30 per cent claimed that this was due to high bank fees. At almost 50 per cent of companies, wages are paid in cash because employees prefer this method of wage payment. This ratio could shrink as electronic payments become widespread, as nowadays no electronic payment options are offered at several acquirers. In many regions, the acquiring network is not mature enough to offer electronic payments (Kajdi - Nemecskó 2020). The introduction of instant payments provides a wide range of retailers with an opportunity to accept electronic payments, which may reduce the share of cash payments. In the case of the retailers using cash wage payment, no clear underlying reason could be detected, with all three factors listed here (bank fees, cash revenues, employee preferences) reported by 60 per cent of respondents. This shows that all of these reasons play a crucial role in cash wage payments.

\subsection{Choice of bank and banking costs}

Businesses consider several aspects when choosing an account-servicing bank, which was assessed using qualitative questions. For companies, the most important issue is banking costs, with 30 per cent of respondents choosing a bank based on this. In-person administration at branches was important for 20 per cent of firms, the availability of ATMs was considered by 10 per cent, while 20 per cent chose the bank servicing their retail account. Favourable lending conditions, a card acquiring service and a mobile banking application were important for 5 per cent of companies.

In the case of retailers, 32 per cent made their choice based on costs, but in this segment the most important factor was in-person administration: 42 per cent of retailers deemed it crucial to have a branch nearby, and for 28 per cent the availability of ATMs was also key. The importance of existing banking relationships was similar to that seen with companies: while a relatively large group (one third) of retailers chose the bank servicing their retail account for their business needs, 
existing loans played a minor role (8 per cent). In a positive development, 16 per cent reported that a mobile banking application was important.

\subsection{Instant payment}

Since the data were collected before the introduction of instant payments in Hungary on 2 March 2020, the preliminary information of Hungarian firms on instant payments could also be analysed. More than half of the respondents in the retail sector and two thirds of companies had heard about instant payments even before the service was launched. One third of retailers and 65 per cent of companies had heard that it was possible to connect to the central infrastructure not only through banks but also through non-bank service providers or even directly. This kind of financial awareness may enhance competition among service providers in the future.

As regards the acceptance of instant payments by retailers, 68 per cent reported that pricing was the most important aspect; in other words, they would consider introducing this option if the related fees were more favourable than the current card acquiring conditions. The immediate receipt of the purchase price was deemed the most important by a much smaller group (18 per cent), although this was typically the second most important factor behind pricing. Customers' aspects ('it should be at least as convenient as card payments') and the fact that they can gain an even better understanding of their customers' buying habits through mobile payments and the various related benefit programmes were only considered important by a small share of retailers. In the case of non-retail companies, there was no material difference when prioritising the above-mentioned aspects.

\section{Conclusions}

This study examined the payment habits of retailers and companies in Hungary, using the data from two questionnaire-based surveys, and other administrative databases (e.g. online cash register data) were also analysed to identify even more accurate correlations. Key differences were observed between the two sectors (retail and corporate) under review: while retailer payments are much more cash intensive and basically the only electronic payment method retailers use is bank card payment, credit transfers play a huge role in the lives of companies, and the cash use ratio is lower in this segment.

Major differences can be detected in payments across the different size categories based on companies' headcount, with smaller firms attaching much greater importance to cash. Considering smaller companies or the retail segment as a whole, the proportion of the businesses that pay the majority of wages in cash is still relatively high. This is probably because most of their revenues are also generated in cash. 
Among the factors influencing card acquiring, size is the most dominant, and the results show that it is also negatively influenced by cash wage payments, which raises the question whether this is simply a feature of the shadow economy or it is also affected by earlier habits and employee preferences. The analysis shows that there is a positive correlation between average purchase value and card acquiring, which is consistent with past results indicating that card payments are more common in the case of larger-value purchases. This may be the cause of the indirect effect that people expect electronic payment alternatives in the stores where larger amounts are typically paid, thereby forcing stores to provide them. Although lifetime is a very significant variable, it has a slightly negative effect on card acquiring. This may be because the stores that were opened later are more likely to be acquirers. A review of the responses by those not accepting cards shows that customers do not demand the card payment option, although this is quite difficult to examine, and a web of interrelated causes is outlined: customers do not demand card payments (they do not say that they would like to pay electronically), therefore POS terminals are not ubiquitous, and due to the large amount of incoming cash payments and the lack of electronic payment methods, employees receive their wages in this manner. The other main reason for not providing a card payment option was high costs.

Accordingly, the micro and small enterprise segment should be primarily targeted with public policy measures if the more widespread use of electronic payment methods is to be achieved. Since the cost factor is key for this group, instant payments, which are much cheaper to establish relative to earlier acquiring methods, may play an important role in this as well.

The widespread application of instant payments and the requirement that retailers using an online cash register must accept electronic payments from 2021 could probably further boost the share of stores accepting electronic payments. For example, payment solutions based on credit transfers may appear in retail trade, and therefore this analysis may provide a useful snapshot of the period before instant payments and compulsory acceptance were introduced, later serving as a benchmark for comparing the next stage of development. As the widespread adoption of instant payments could provide a solution for several market issues, it is promising that the overwhelming majority of retailers and companies have heard about instant payments, which may lend impetus to the development of services from the demand side. 


\section{References}

Bartha, L. - Luspay, M. - Varga, L. (2017): Pénzforgalom és pénzügyi infrastruktúrák (Payments and financial infrastructures). In: Vonnák, B. (ed.): Modern jegybanki gyakorlat (Modern Central Bank Practices). Magyar Nemzeti Bank, pp. 287-360.

Belházyné Illés, Á. - Végső, T. - Bódi-Schubert, A. (2018): An Analysis of the Payment Habits of Hungarian Micro, Small and Medium-sized Enterprises - In Focus: Cash Usage. Financial and Economic Review, 17(4): 53-94. http://doi.org/10.25201/FER.17.4.5394

Bódi-Schubert, A. (2014): Bizalom(hiány) és fizetési magatartás a kis- és középvállalatok üzleti kapcsolataiban ((Lack of) Confidence and payment behaviour in the business relations of small and medium-sized enterprises). MNB Occasional Papers 110, Magyar Nemzeti Bank. https://www.mnb.hu/letoltes/mt110-vegleges.pdf

Bounie, D. - François, A. - Van Hove, L. (2017): Consumer Payment Preferences, Network Externalities, and Merchant Card Acceptance: An Empirical Investigation. Review of Industrial Organization, 51(3): 257-290. https://doi.org/10.1007/s11151-016-9543-y

Dahlberg, T. - Öörni, A. (2008): Understanding Changes in Consumer Payment Habits - Do Mobile Payments Attract Consumers? Sprouts, Working Papers on Information Systems. https://www.academia.edu/5822166/Understanding_Changes_in_Consumer_Payment_ Habits_Do_Mobile_Payments_Attract_Consumers. Downloaded: 23 January 2021.

The Danish Payments Council (2019): Business-to-business payments entailed social costs of kr. 4.2 billion. Series: Costs of payments in Denmark 2016. https://www.nationalbanken. dk/en/publications/Documents/2019/02/BR_Business-to-business\%20payments\%20 in\%20Denmark\%202016.pdf. Downloaded: 19 January 2021.

ECB (2020): Study on the payment attitudes of consumers in the euro area (SPACE). European Central Bank, December. https://www.ecb.europa.eu/pub/pdf/other/ecb. spacereport202012 bb2038bbb6.en.pdf

Górka, J. (2012): Payment Behaviour in Poland - The Benefits and Costs of Cash, Cards and Other Non-Cash Payment Instruments. https://www.bundesbank.de/resource/ blob/635066/b8afafb1655f5d7d89332d836367454a/mL/2012-02-27-eltville-09-gorkapaper-data.pdf. Downloaded: 11 March 2021.

Gresvik, O. - Haare, H. (2008): Payment habits at point of sale. Norges Bank, Staff Memo No. 6. https://www.norges-bank.no/globalassets/upload/publikasjoner/staff-memo/2008/ staff_memo_2008_06.pdf?v=03/09/2017122428\&ft=.pdf

Harasim, J. - Klimontowicz, M. (2013): Payment Habits as a Determinant of Retail Payment Innovations Diffusion: the Case of Poland. Journal of Innovation Management, 1(2): 86102. https://doi.org/10.24840/2183-0606_001.002_0007 
Ilyés, T. - Varga, L. (2015): Show me how you pay and I will tell you who you are - Sociodemographic determinants of payment habits. Financial and Economic Review, 14(2): 26-61 https://en-hitelintezetiszemle.mnb.hu/letoltes/2-ilyes-varga-en.pdf

Ilyés, T. - Varga, L. (2018): Acceptance of Payment Cards by Retailers in Hungary Based on Data of Online Cash Registers. Financial and Economic Review, 17(1): 83-109. http://doi. org/10.25201/FER.17.1.83109

Jonker, N. - Hernandez, L. - de Vree, R. - Zwaan, P. (2018): From cash to cards: how debit card payments overtook cash in the Netherlands. De Nederlandsche Bank - Dutch Payments Association, Occasional Studies Volume 16-1. https://www.dnb.nl/media/ kx1akmnb/201802_nr_1_-2018-_from_cash_to_cards_how_debit_card_payments_ overtook_cash_in_the_netherlands.pdf

Kajdi, L. - Nemecskó, I. (2020): Regional Features of Card Payments in Hungary. Financial and Economic Review, 19(1): 65-89. http://doi.org/10.33893/FER.19.1.6589

Kosse, A. - Chen, H. - Felt, M. - Jiongo, V.D. - Nield, K. - Welte, A. (2017): The Costs of Point-of-Sale Payments in Canada. Bank of Canada, Staff Discussion Paper 2017-4. https:// www.bankofcanada.ca/wp-content/uploads/2017/03/sdp2017-4.pdf

Leinonen, H. (2008): Payment habits and trends in the changing e-landscape 2010+. Bank of Finland Expository Studies A:111. https://www.finextra.com/finextra-downloads/ featuredocs/a111.pdf

Loke, Y.J. (2007): Determinants of Merchant Participation in Credit Card Payment Schemes. Review of Network Economics, 6(4):1-22. https://doi.org/10.2202/1446-9022.1130

Takács, K. (2011): A magyar háztartások fizetési szokásai (Payment Habits of Hungarian Households). MNB Occasional Papiers 98, Magyar Nemzeti Bank. https://www.mnb.hu/ letoltes/mt98.pdf

Turján, A. - Divéki, É. - Keszy-Harmath Zoltánné - Kóczán, G. - Takács, K. (2011): Nothing is free: A survey of the social cost of the main payment instruments in Hungary. MNB Occasional Papiers 93, Magyar Nemzeti Bank. https://www.mnb.hu/letoltes/op93-fmtk.pdf 